\title{
Töiden organisointi perustuotanto- ja monialaisilla tiloilla
}

\author{
Janne Karttunen ${ }^{1)}$ ja Veli-Matti Tuure ${ }^{1)}$ \\ ${ }^{1)}$ TTS tutkimus, PL 5, 05201 Rajamäki, \\ janne.karttunen@tts.fi,veli-matti.tuure@tts.fi
}

\section{Tiivistelmä}

Tutkimusaineiston rungon muodostaa marras-joulukuussa 2006 tehty Muuttuva maaseutuyrittäjyysyhteistutkimuksen (MuuMaa) postikysely, jossa TTS:n tutkimusosion lopullisiksi palautusprosenteiksi saatiin perustuotantotiloilla 27,5 $\left(\mathrm{n}_{1}=230\right)$ ja monialaisilla tiloilla $34,3\left(\mathrm{n}_{2}=433\right)$. MuuMaa-aineistoa täydennettiin MTT Taloustutkimuksen kannattavuuskirjanpitotiloille tekemällä kyselyllä, jonka TTS:n tutkimusosioon saatiin käyttökelpoiset vastaukset yhteensä 411 tilalta, jolloin vastausprosentti oli 45,3.

TTS:n tutkimusosion tavoitteena on selvittää maatalousyritysten töiden organisoinnin päälinjat maassamme sekä maatalousyrittäjien mielipiteet tilayhteistyöstä ja töiden ulkoistamisesta. Lopullisena tavoitteena on löytää yrittäjien jaksamista edistäviä ja tilan tuotantokapasiteetin käyttöastetta nostavia toimintamalleja erityisesti tuotantoaan laajentavien tilojen tarpeisiin. MuuMaa-hanke päättyy toukokuussa 2008.

Tulosten mukaan erityisesti nurmen viljelyssä, lannan levityksessä ja viljan puinnissa sekä tilayhteistyö että töiden ulkoistaminen tai niiden ja oman työn yhdistelmät ovat suosittuja. Syitä voivat olla kausiluontoisten töiden vaatima hetkellinen suuri työvoiman tarve tai kalliit koneinvestoinnit tai molemmat. Puhtaan tilayhteistyön tai töiden ulkoistamisen yleisyys vaihtelee hyvin paljon eri töiden välillä. Monessa työssä tilayhteistyön tai ulkoistamisen suhteellinen yleisyys kaksin- jopa kolminkertaistuu, kun otetaan huomioon myös edellä mainittujen ja oman työn yhdistelmät.

Perustuotanto- ja monialaisten tilojen harjoittamassa tilayhteistyössä korostetaan sen tuomia taloudellisia etuja: tuotantopanosten ja koneiden hankkiminen sekä joidenkin töiden tekeminen yhteistyössä koetaan edullisemmaksi kuin yksin toimiminen. Lisäksi yhteistyön koetaan antavan henkisiä virikkeitä. Tietyt erot töiden ulkoistamista koskevissa mielipiteissä voivat johtua siitä, että perustuotantotilat ovat voineet vastata lähinnä asiakkaan näkökulmasta ja monialaiset tilat puolestaan palvelun tarjoajan näkökulmasta. Siitä oltiin selvästi samaa mieltä, että ulkoistamisen koettiin vähentävän työperäistä kuormitusta.

Tämän tutkimuksen ehkä yllättävin löydös on, että kaikista kp-tiloista vain noin kymmenesosa ja lypsykarjatiloista vain viisi prosenttia tekee kaikki tilan keskeiset maatilatalouden työt omin voimin. Lopuilla kp-tiloista vähintään muutamia maatilatalouden töistä on joko ulkoistettu tai tehdään tilayhteistyössä.

Maatalousyrityksen töiden huolellinen suunnittelu ja järkevä organisointi ulkoistamalla, tilayhteistyöllä tai niiden ja oman työn yhdistelmillä ovat keinoja parantaa yrityksen tuotantokapasiteetin käyttöastetta. Töiden organisointikeinot eivät ole toisiaan poissulkevia. Tämän tutkimuksen mukaan kuvaavaa maamme keskikokoisille ja sitä suuremmille maatalousyrityksille on monimuotoisuus töiden organisoinnissa.

Tulosten päälinjat kuvannevat hyvin maatilatalouden keskeisten töiden organisointia sekä yrittäjien asenteita tilayhteistyötä ja töiden ulkoistamista kohtaan keskikokoisilla ja niitä jossain määrin suuremmilla tiloilla. Niiden sekä maamme suurimpien tilojen joukosta löytyvät todennäköisimmin tuotantoaan edelleen kehittävät ja pitkään jatkavat tilat, mikä parantaa tulosten pysyvyyttä.

Asiasanat: maaseutu, monialaisuus, yhteistyö, ulkoistaminen, töiden organisointi, jaksaminen 


\section{Johdanto}

Maassamme oli vuonna 2005 noin 60000 aktiivista maatalousyritystä. Aktiivitilalla on käytössään maatalousmaata vähintään yksi hehtaari tai kotieläimiä vähintään yhden kotieläinyksikön verran. Aktiivitilojen peltoala oli keskimäärin noin 33 ja metsämaa-ala noin 50 hehtaaria. Metsätalouden harjoittaminen on tunnusomaista lähes kaikille maamme aktiivitiloille: selvästi yli $90 \%$ :lla on metsämaata omistuksessaan. Aktiivitiloista noin 45000 oli perinteisiä maatalousyrityksiä (jatkossa: perustuotantotila) eli niillä harjoitetaan vain maa- ja metsätaloutta. Vastaavasti niitä aktiivitiloja, joilla harjoitetaan myös muun toimialan yritystoimintaa, kutsutaan monialaisiksi maatalousyrityksiksi (jatkossa: monialainen tila). Monialaisia tiloja oli maassamme vuonna 2005 noin 24300 eli runsas kolmasosa kaikista aktiivitiloista. (Tike 2007).

Monialaisuus on yleisintä peltopinta-alaltaan suurilla viljatiloilla. Yli kaksi kolmasosaa (68 \%) monialaisista tiloista tarjoaa erilaisia palveluita, joista koneurakointi on ylivoimaisesti yleisintä. Noin 10000 monialaista tilaa ilmoittaa toisille maatalousyrittäjille tai esimerkiksi kunnalle tehtävän koneurakoinnin liikevaihdoltaan tärkeimmäksi maatalouden ulkopuoliseksi toimialaksi. (Tike 2007).

Monialaisuus on perinteisesti ollut Suomessa yleistä maatalousyrittäjien keskuudessa. Kuluvalla vuosikymmenellä monialaisten tilojen määrä ja suhteellinen osuus on kuitenkin kasvanut selvästi (Tike 2007). Koska vain osa toimintaansa kehittävistä maatalousyrittäjistä tai yrittäjäperheistä voi ja haluaa kasvattaa tilakokoaan, on tulolähteiden hankkiminen alkutuotannon ulkopuolelta - monialaistaminen - vaihtoehto vastata maatalouden jatkuvaan rakennemuutostarpeeseen (Peltola 2000).

Horisontaalisessa monialaistamisessa maatalousyritys laajentaa toimintojaan niille aloille ja tuotteisiin, jotka ovat hyvin lähellä sen alkuperäistä toimialaa. Hyvä esimerkki tästä on maatalouskoneurakointi. Vertikaalisessa monialaistamisessa maatalousyritys integroituu joko ylös- tai alaspäin tuotantoketjussa. (Rantamäki-Lahtinen 2004). Esimerkiksi naudanlihaa tuottava tila voi jatkojalostaa omia lihatuotteitaan.

Hajauttaminen alkutuotannon ulkopuolelle tuo maatalousyrityksen johtamiseen ja kehittämiseen isoja lisähaasteita. Monialaisuuden keskeisin riski on yrityksen voimavarojen pirstaloituminen liian moneen asiaan, jolloin yrityskokonaisuus kärsii. Niemelän ym. (2005) mukaan monialaisten tilojen joukon sisällä onkin jonkin verran vaihtuvuutta - esimerkiksi Rantamäki-Lahtisen (2004) tutkimuksessa noin viidennes monialayrittäjistä aikoi siirtyä takaisin pelkän maatilatalouden harjoittamiseen.

Sekä monialaisilla että voimakkaasti laajentavilla perustuotantotiloilla työvoiman ja osaamisen riittävyys sekä yrittäjän tai yrittäjäperheen jaksaminen voivat nousta kynnyskysymyksiksi (Rantamäki-Lahtinen 2004). Keskeinen keino alentaa viljelijäperheen vuotuista työmäärää ja tapaturmariskiä sekä tuotannon yksikkökustannuksia on organisoida maataloustöitä uudelleen ulkoistamalla osa töistä tai kehittämällä tilayhteistyötä tai edellä mainittujen keinojen yhdistelmällä (Karttunen ym. 2006, Karttunen 2004).

Suomen Gallup Elintarviketiedon (2005) viljelijäkyselyn mukaan tilayhteistyö on erityisesti nuorten viljelijöiden suosiossa. Tyypillisimmät yhteistyömuodot ovat koneyhteistyö, koneiden yhteisomistajuus ja tuotantopanosten yhteishankinnat. Niemelän ym. (2005) mukaan myös monialaiset tilat pyrkivät aktiivisesti yhteistyöhön toisten maatalousyritysten kanssa. Tilayhteistyön huippuna voidaan pitää maatalousyhtymän perustamista. Ns. maitoyhtymiä on Karttusen (2004) mukaan noin viidesosa Suomessa suurehkoiksi luokiteltavista, vähintään 40 lypsylehmän, maitotiloista. Niistä noin kolmasosa on kahden naapuritilan muodostamia ja noin kaksi kolmasosaa kahden tai useamman samalla tilalla asuvan henkilön muodostamia.

Lätin ym. (2006) mukaan maitoyhtymissä työmäärän vähentyminen tuotettua yksikköä kohden sekä töiden sitovuuden vähentyminen voivat olla todella merkittäviä, ja samaan aikaan saavutetaan myös suurtuotannon etuja karjakoon huomattavalla kasvulla. Kasvinviljelytilojen ja karjatilojen välinen yhteistyö on myös todettu suositeltavaksi (Lätti ym. 2006). Kirkkarin ym. (1998) tutkimuksen mukaan tilayhteistyön merkittävimmäksi eduksi nimettiin taloudelliset säästöt, mutta myös sosiaalisia hyötyjä arvostettiin.

\section{Tutkimuksen tavoite}

Yhteishankkeen "Muuttuva maaseutuyrittäjyys" tässä artikkelissa kuvatun TTS tutkimuksen osion tavoitteena on selvittää maatalousyritysten töiden organisoinnin päälinjat tällä hetkellä maassamme sekä maatalousyrittäjien mielipiteet tilayhteistyöstä ja töiden ulkoistamisesta. Lisäksi artikkelissa vertaillaan toisaalta perustuotanto- ja monialaisten tilojen sekä toisaalta maidontuotantotilojen ja muita tuotantosuuntia edustavien tilojen välisiä eroja tilan töiden organisoinnissa.

TTS tutkimuksen tutkimusosion lopullisen tavoitteena on löytää yrittäjien jaksamista edistäviä ja tilan tuotantokapasiteetin käyttöastetta nostavia toimintamalleja erityisesti tuotantoaan voimakkaasti laajentavien perustuotantotilojen ja monialaisten tilojen tarpeisiin. 


\section{Aineisto ja menetelmät}

Yhteistutkimus "Muuttuva maaseutuyrittäjyys - Monialaisten tilojen, perusmaatilojen ja maaseudun muiden yritysten yrittäjyys ja resurssienhallinta 2000-2006" (jatkossa: MuuMaa) alkoi toukokuussa 2006 ja päättyy toukokuussa 2008. Tutkimusosapuolia ovat MTT taloustutkimus, HY:n sosiaalipsykologian laitos ja TTS tutkimus. MTT:n koordinoima tutkimus rahoitetaan maa- ja metsätalousministeriön maatilatalouden kehittämisrahastosta.

\section{Aineisto 1: MuuMaa-tutkimuksen kysely}

Tutkimusaineiston rungon muodostaa marras-joulukuussa 2006 tehty MuuMaa-tutkimuksen postikysely, johon saattoi vastata myös sähköisesti. Etukäteen testattu kyselylomake oli 12 sivun mittainen, ja se koostui yhteensä 60 kysymyskohdasta, joissa useimmissa oli useita alakysymyksiä. Kysymykset olivat suurimmaksi osaksi strukturoituja monivalintakysymyksiä.

Postikyselyn otoksessa ( $n=2895)$ olivat edustettuina perinteiset maatalousyrittäjät/perustuotantotilat $\left(\mathrm{n}_{1}=835\right)$, monialaiset maatalousyrittäjät/monialaiset tilat $\left(\mathrm{n}_{2}=1263\right)$ ja muut maaseudun yrittäjät, joilla ei ole maatalouskytkentää $\left(\mathrm{n}_{3}=797\right)$. TTS:n tutkimusosion (seitsemän strukturoitua monivalintakysymystä) kohderyhmänä olivat perustuotanto- ja monialaiset tilat.

Ensimmäisellä postituksella palautui 581 ja muistutuspostituksella 324 lomaketta. Sähköisen lomakkeen täyttäneitä oli 39 henkilöä, mikä oli 4,5 \% kaikista palautuneista lomakkeista. Puutteellisesti vastattujen lomakkeiden poistamisen jälkeen saatiin TTS:n tutkimusosion lopullisiksi palautusprosenteiksi perinteisillä maatalousyrittäjillä 27,6 (n' $\left.{ }_{1}=230\right)$ ja monialaisilla maatalousyrittäjillä 34,3 (n' 2

\section{Aineisto 2: kysely kannattavuuskirjanpitotiloille}

TTS tutkimus täydensi edellä kuvattua aineistoa MTT Taloustutkimuksen kannattavuuskirjanpitotiloille ( $\mathrm{n}=907)$ keväällä 2005 tekemällä kyselyllä, johon TTS:n toimesta laadittiin strukturoitu monivalintakysymys. Kannattavuuskirjanpitoon kuuluvat tilat (jatkossa: kp-tilat) ovat keskimäärin suurempia kuin tilat keskimäärin maassamme, mutta myös niiden koossa on paljon vaihtelua. Kp-tiloihin kuuluu käytännössä sekä perustuotanto- että monialaisia tiloja, mutta ne jaotellaan tarkasteluissa tuotantosuunnan ja koon mukaan.

TTS sai omaan kysymykseensä sekä keskeisiin taustamuuttujiin käyttökelpoiset vastaukset yhteensä $411 \mathrm{kp}$-tilalta, jolloin vastausprosentti on 45,3. Vastanneista tiloista 179:1lä harjoitettiin maidontuotantoa. Osalla lypsykarjatiloista oli myös muuta karjaa, useimmiten lihakarjaa. 93 tilalla oli muita tuotantoeläimiä kuin lypsykarjaa: lihanautoja ja/tai emolehmiä oli 25 tilalla, sikataloutta harjoittavia tiloja oli $45 \mathrm{kpl} \mathrm{ja}$ muuta kotieläintaloutta, useimmiten siipikarjaa, oli 23 tilalla. 139 tilalla harjoitettiin vain kasvinviljelyä useimmilla viljan tai öljykasvien tai molempien viljelyä.

\section{Katoanalyysi ja aineiston edustavuus}

MTT:n laatiman katoanalyysin mukaan aineistossa 1 kyselylomakkeen palauttaneiden ja palauttamatta jättäneiden yrittäjäryhmien välillä ei ollut merkittävää eroa yrityksen päätuotantosuunnassa, pelto- tai metsäpinta-alassa tai yrityksen maantieteellisessä sijainnissa.

Aineistossa 2 kyselyyn vastanneiden tilojen peltoala (oma ja vuokrapelto yhteensä) oli keskimäärin 54 hehtaaria ja metsäala 81 hehtaaria. Näin ollen kyselyyn vastanneet tilat olivat keskimäärin suurempia kuin tilat kyselyhetkellä maassamme keskimäärin, mutta vastanneiden tilojen koossa oli paljon vaihtelua.

Kyselyyn vastanneilla lypsykarjatiloilla oli keskimäärin 25 lehmää - keskihajonta 12, keskiluku 21, minimi 1 ja maksimi 70 lehmää. Näin ollen kyselyyn vastanneet lypsykarjatilat olivat karjamäärältään keskimäärin hieman suurempia kuin keskikokoiset maitotilat (noin 21 lehmää/tila) kyselyhetkellä maassamme.

\section{Menetelmät}

Tässä kirjoituksessa esitetään alustavia tuloksia frekvenssijakaumien ja suhteellisten frekvenssien muodossa. Aineistosta 1 käydään läpi vastaukset kahteen seitsemästä TTS:n tutkimusosion monivalintakysymyksestä. Niiden avulla vertaillaan perustuotanto- ja monialaisia tiloja keskenään töiden organisointiin liittyvien arvostuksien ja asenteiden suhteen. Aineisto 2:n yhden monivalintakysymyksen avulla vertaillaan maidontuotantotiloja, muita karjatiloja sekä kasvinviljelytiloja keskenään töiden organisointitapojen - oman työn, tilayhteistyön ja töiden ulkoistamisen tai niiden yhdistelmien - suhteen. 


\section{Tulokset ja tulosten tarkastelu}

Seuraavassa tarkastellaan ensin aineiston 2 avulla keskeisten maatilatalouden töiden, ml. hallinnointityöt, organisointia kannattavuuskirjanpitoon kuuluvilla lypsykarjatiloilla, muilla karjatiloilla ja kasvinviljelytiloilla. Tämän jälkeen tarkastellaan aineiston 1 avulla perustuotantotilojen ja monialaisten tilojen töiden organisointia sekä omistajien mielipiteitä tilayhteistyöstä ja töiden ulkoistamisesta. Tarkastelun pohjalta tehtävät johtopäätökset ovat yhteiset molemmille aineistoille.

\section{Tilayhteistyö kp-tiloilla}

Kaikissa kolmessa tilaryhmässä tilayhteistyönä tehtävistä töistä suhteellisesti yleisin on nurmisadon korjuu (taulukko 1). On kuitenkin huomattava, että vain osalla kasvinviljelyä tai muuta karjataloutta harjoittavista tiloista nurmenviljelyn eri työtehtävät kuuluvat tilan töihin. Seuraavaksi yleisimpiä yhteistyönä tehtäviä töitä ovat viljan puinti sekä lannanlevitykseen ja perunan tai sokerijuurikkaan viljelyyn liittyvät työt. Vastaajat eivät ilmeisesti ole sisällyttäneet perunanviljelyyn pelkän oman ruokaperunan viljelyä.

Taulukko 1. Prosenttiluku kertoo kunkin työn kohdalla, kuinka suurella osalla vuonna 2005 kirjanpitoon kuuluneista tiloista kyseinen työ tehtiin joko kokonaan tilayhteistyönä tai tilayhteistyön, urakoinnin ja oman työn yhdistelminä. Kunkin tilaryhmän viisi suhteellisesti useimmiten tilayhteistyönä tehtyä työtä on korostettu.

\begin{tabular}{|c|c|c|c|c|c|c|}
\hline & \multicolumn{2}{|c|}{$\begin{array}{c}\text { Lypsykarjatilat } \\
n=179\end{array}$} & \multicolumn{2}{|c|}{$\begin{array}{c}\text { Muut karjatilat } \\
\mathrm{n}=93\end{array}$} & \multicolumn{2}{|c|}{$\begin{array}{c}\text { Kasvinviljelytilat } \\
\mathrm{n}=139\end{array}$} \\
\hline & $\begin{array}{l}\text { kuuluu } \\
\text { tilan töi- } \\
\text { hin, } \\
\text { tiloja kpl }\end{array}$ & $\begin{array}{c}\text { tilayhteis- } \\
\text { työ } \\
\%\end{array}$ & $\begin{array}{l}\text { kuuluu } \\
\text { tilan töi- } \\
\text { hin, } \\
\text { tiloja kpl }\end{array}$ & $\begin{array}{l}\text { tilayhteis- } \\
\text { työ } \\
\%\end{array}$ & $\begin{array}{l}\text { kuuluu } \\
\text { tilan töi- } \\
\text { hin, tiloja } \\
\text { kpl }\end{array}$ & $\begin{array}{l}\text { tilayhteis- } \\
\text { työ } \\
\%\end{array}$ \\
\hline säilörehunkorjuu & 170 & 41 & 37 & 35 & 15 & 27 \\
\hline kuivaheinän korjuu & 134 & 14 & 30 & 20 & 15 & 7 \\
\hline perunan/juurikkaan nosto & 37 & 8 & 20 & 15 & 48 & 19 \\
\hline tuotantotarvikkeiden osto & 177 & 7 & 93 & 3 & 137 & 8 \\
\hline viljan puinti & 148 & 7 & 87 & 11 & 133 & 13 \\
\hline kasvinsuojelutyöt & 153 & 6 & 84 & 1 & 129 & 7 \\
\hline lietteen ajo & 132 & 6 & 50 & 8 & 24 & 17 \\
\hline kevätkylvöt & 175 & 5 & 91 & 7 & 134 & 9 \\
\hline kuivalannan ajo & 106 & 5 & 66 & 9 & 20 & 20 \\
\hline nurmien lannoitus & 163 & 5 & 38 & 5 & 24 & 17 \\
\hline perunan/juurikkaan istutus & 39 & 5 & 18 & 33 & 48 & 17 \\
\hline kevätmuokkaus & 179 & 4 & 85 & 6 & 132 & 8 \\
\hline syysmuokkaus & 161 & 4 & 87 & 3 & 123 & 6 \\
\hline pilkkeiden teko/haketus & 173 & 3 & 90 & 4 & 127 & 3 \\
\hline metsätyöt & 166 & 3 & 90 & 3 & 135 & 1 \\
\hline EU-tukihakemukset & 177 & 2 & 93 & 2 & 138 & 4 \\
\hline veroilmoitus & 177 & 2 & 91 & 1 & 137 & 3 \\
\hline kirjanpito & 178 & 1 & 92 & 0 & 136 & 2 \\
\hline
\end{tabular}

Tuotantotarvikkeiden yhteisostot ovat jossain määrin suosittuja lypsykarja- ja kasvinviljelytiloilla, mutta muilla karjatiloilla harvinaisia. Se voi johtua siitä, että erityisesti sika- ja siipikarjatiloilla ei välttämättä ole lähiseudulla toista saman tuotantosuunnan tilaa, jonka kanssa voisi tehdä tällaista yhteistyötä.

On todennäköistä, että joillakin kp-tiloilla tiettyä työtä ei varsinaisesti tehdä yhdessä, vaan työ tehdään itse, mutta käyttäen yhteisiä tai naapurilta lainattavia koneita. Vastaavasti tilayhteistyönä tehtävät työt eivät välttämättä vaadi yhteisten koneiden omistamista.

\section{Töiden ulkoistaminen kp-tiloilla}

Metsätyöt on ylivoimaisesti yleisin maamme maatalousyrityksissä ulkoistettu työ tai paremminkin töiden ryhmä (taulukko 2). Noin kolme viidesosaa kaikkia tuotantosuuntia edustavista kp-tiloista ilmoittaa ulkoistaneensa kyseisen työn. Viljan puinti on kirjanpitoon kuuluvilla lypsykarjatiloilla selvästi yleisin ulkoistettu peltoviljelytyö, mutta niillä muista karjatiloista ja kasvinviljelytiloista, joilla nurmen viljely kuuluu tilan töihin, vastaavan sijan saa säilörehunkorjuu. Viimeksi mainituilla tiloilla nurmen korjuu on ulkoistettu poikkeuksellisen usein. Lannanlevitykseen liittyvät työt - lietteen tai kuivalannan ajo - ovat suhteellisesti toiseksi yleisimmät ja säilörehunkorjuu kolmanneksi yleisin ulkoistettu peltoviljelytyö lypsykarjatiloilla. Toisinaan 
koneketjusta ulkoistetaan vain jokin tietty osa, kuten varsinainen rehunkorjuu. Muut ketjun osat ja niissä käytettävät koneet tulevat joko omasta takaa tai tilayhteistyön kautta - vaihtoehtoja on monia.

Taulukko 2. Prosenttiluku kertoo kunkin työn kohdalla, kuinka suurella osalla vuonna 2005 kirjanpitoon kuuluneista tiloista kyseinen työ tehtiin joko kokonaan ulkoistettuna tai urakoinnin, tilayhteistyön ja oman työn yhdistelminä. Kunkin tilaryhmän viisi suhteellisesti useimmiten ulkoistettuna tehtyä työtä on korostettu.

\begin{tabular}{|c|c|c|c|c|c|c|}
\hline & \multicolumn{2}{|c|}{$\begin{array}{l}\text { Lypsykarjatilat } \\
n=179\end{array}$} & \multicolumn{2}{|c|}{$\begin{array}{c}\text { Muut karjatilat } \\
\mathrm{n}=93\end{array}$} & \multicolumn{2}{|c|}{$\begin{array}{l}\text { Kasvinviljelytilat } \\
n=139\end{array}$} \\
\hline & $\begin{array}{l}\text { kuuluu } \\
\text { tilan töi- } \\
\text { hin, } \\
\text { tiloja kpl }\end{array}$ & $\begin{array}{c}\text { ulkoistettu } \\
\text { \% }\end{array}$ & $\begin{array}{l}\text { kuuluu } \\
\text { tilan töi- } \\
\text { hin, } \\
\text { tiloja kpl }\end{array}$ & $\begin{array}{c}\text { ulkoistettu } \\
\text { \% }\end{array}$ & $\begin{array}{l}\text { kuuluu } \\
\text { tilan töi- } \\
\text { hin, tiloja } \\
\text { kpl }\end{array}$ & $\begin{array}{c}\text { ulkoistettu } \\
\%\end{array}$ \\
\hline metsätyöt & 166 & 61 & 90 & 60 & 135 & 57 \\
\hline viljan puinti & 148 & 36 & 87 & 16 & 133 & 21 \\
\hline veroilmoitus & 177 & 27 & 91 & 24 & 137 & 18 \\
\hline pilkkeiden teko/haketus & 173 & 24 & 90 & 30 & 127 & 14 \\
\hline lietteen ajo & 132 & 23 & 50 & 16 & 24 & 38 \\
\hline EU-tukihakemukset & 177 & 22 & 93 & 8 & 138 & 5 \\
\hline säilörehunkorjuu & 170 & 21 & 37 & 49 & 15 & 73 \\
\hline kasvinsuojelutyöt & 153 & 14 & 84 & 15 & 129 & 5 \\
\hline kuivaheinän korjuu & 134 & 13 & 30 & 33 & 15 & 27 \\
\hline kuivalannan ajo & 106 & 12 & 66 & 18 & 20 & 5 \\
\hline perunan/juurikkaan istutus & 39 & 10 & 18 & 0 & 48 & 4 \\
\hline kirjanpito & 178 & 8 & 92 & 11 & 136 & 8 \\
\hline kevätkylvöt & 175 & 7 & 91 & 2 & 134 & 8 \\
\hline perunan/juurikkaan nosto & 37 & 5 & 20 & 15 & 48 & 10 \\
\hline syysmuokkaus & 161 & 4 & 87 & 6 & 123 & 5 \\
\hline kevätmuokkaus & 179 & 2 & 85 & 2 & 132 & 2 \\
\hline nurmien lannoitus & 163 & 2 & 38 & 8 & 24 & 4 \\
\hline tuotantotarvikkeiden osto & 177 & 1 & 93 & 0 & 137 & 0 \\
\hline
\end{tabular}

Erityisesti nurmen viljelyyn, lannan levitykseen ja viljan puintiin liittyvät työt kuuluvat maatilatalouden töihin, joissa sekä tilayhteistyö että ulkoistaminen tai niiden ja oman työn yhdistelmät ovat varsin suosittuja. Syitä voivat olla kausiluontoisten töiden vaatima hetkellinen suuri työvoiman tarve tai kalliit koneinvestoinnit tai molemmat.

Tarkasteltaessa kp-tilojen töiden organisoinnista antamia alkuperäisiä vastauksia voidaan havaita, että puhtaan tilayhteistyön tai töiden ulkoistamisen yleisyys vaihtelee hyvin paljon eri töiden välillä. Monessa työssä tilayhteistyön tai ulkoistamisen suhteellinen yleisyys kaksin- jopa kolminkertaistuu, kun otetaan huomioon myös edellä mainittujen ja oman työn yhdistelmät.

Metsätöissä yleisesti ja erityisesti lypsykarjatiloilla säilörehun korjuussa on useammin käytössä töiden organisointitapojen yhdistelmä kuin puhdas urakointi tai tilayhteistyö. Vastaavasti viljan puinnissa ja kasvinsuojeluruiskutuksissa ei juuri ole käytössä organisointitapojen yhdistelmiä. Kaiken kaikkiaan vain 9 lypsykarjatilaa, 9 muuta karjatilaa ja 25 kasvinviljelytilaa ilmoittaa tekevänsä itse kaikki tilalla tehtävät työt. Kaikilla muilla kp-tiloilla on joko ulkoistettu tai tehdään tilayhteistyönä tai niiden ja oman työn yhdistelmänä vähintään yksi, useimmilla useampia kuin yksi, työ.

Kp-tilakyselyssä mainittujen 18 eri maatilatalouden työn lisäksi vastaajat ilmoittivat ulkoistaneensa tai tekevänsä tilayhteistyönä erityisesti viljan kuivausta, kuljetusta ja myyntiä. Ulkoistettuina töinä mainittiin listan ulkopuolelta myös mm. lumen auraus ja teiden ylläpito, rakennustyöt, kalkin levitys ja rahti, koneiden korjaus ja huolto sekä hiehojen hoito.

\section{Tilayhteistyön ja ulkoistamisen merkitys}

Perustuotanto- ja monialaisilla tiloilla arvostetaan pääpiirteissään samoja seikkoja tilayhteistyössä. Tilayhteistyössä korostetaan sen tuomia taloudellisia etuja: tuotantopanosten ja koneiden hankkiminen sekä joidenkin töiden tekeminen yhteistyössä koetaan edullisemmaksi kuin yksin toimiminen (taulukko 3). Lisäksi yhteistyön koetaan antavan henkisiä virikkeitä. Sen sijaan yhdessä tekemisen ei juuri koeta vähentävän työmäärää. Toisaalta väittämää, jonka mukaan tuotantoketjuissa olevia - käytännössä työntekoa hidastavia - pullonkauloja voidaan poistaa yhteistyöllä, pidetään jossain määrin merkittävänä. 
Taulukko 3. Miten merkittäviä seuraavat seikat ovat tilayhteistyössänne? ${ }^{*}$ Kolmen merkittävimmäksi koetun väittämän järjestysnumero on korostettu.

\begin{tabular}{|c|c|c|}
\hline & $\begin{array}{c}\text { Perustuotantotilat }(\mathrm{n}=230) \\
\text { merkittävyys, } \\
\text { 1=eniten...9=vähiten }\end{array}$ & $\begin{array}{c}\text { Monialaiset tilat }(\mathrm{n}=433) \\
\text { merkittävyys, } \\
\text { 1=eniten...9=vähiten }\end{array}$ \\
\hline $\begin{array}{l}\text { Yhteistyö vähentää yrittäjäperheen kuormitusta ja } \\
\text { auttaa jaksamaan työssä }\end{array}$ & 8. & 6. \\
\hline $\begin{array}{l}\text { Yhteistyön on lisääntymässä, mikä lisää yhteistyön } \\
\text { yleistä hyväksyttävyyttä }\end{array}$ & 9. & 8. \\
\hline $\begin{array}{l}\text { Joidenkin töiden tekeminen yhteistyössä on talou- } \\
\text { dellisempaa kuin yksin tekeminen }\end{array}$ & 2. & 1. \\
\hline $\begin{array}{l}\text { Joidenkin tuotantopanosten tai koneiden hankinta } \\
\text { yhteistyössä tulee edullisemmaksi }\end{array}$ & 1. & 3. \\
\hline $\begin{array}{l}\text { Joidenkin yrittäjien asenne estää tai ainakin hidas- } \\
\text { taa yhteistyötä }\end{array}$ & 6. & 7. \\
\hline Yhteistyö edistää yrittäjäperheen työturvallisuutta & 7. & 9. \\
\hline $\begin{array}{l}\text { Tuotantoketjuissa olevia pullonkauloja voidaan } \\
\text { poistaa yhteistyöllä }\end{array}$ & 4. & 4. \\
\hline Yhteistyön tekeminen antaa henkisiä virikkeitä & 3. & 2. \\
\hline Haluan tukea muita yhteistyökumppaneita & 5. & 5. \\
\hline
\end{tabular}

*Järjestysnumeroitu sen mukaan, kuinka monta pistettä väittämä sai vastaajaryhmältä yhteensä skaalalla: erittäin merkittävä (5 p), melko merkittävä (4 p), .., ei lainkaan merkittävä (1 p).

Perustuotanto- ja monialaiset tilat arvostavat suurin piirtein samoja seikkoja töiden ulkoistamisessa (taulukko 4). Tietyt erot mielipiteissä voivat johtua siitä, että perustuotantotilat ovat voineet vastata lähinnä asiakkaan näkökulmasta ja monialaiset tilat puolestaan palvelun tarjoajan näkökulmasta. Siitä oltiin vahvasti samaa mieltä, että ulkoistamisen koettiin vähentävän työperäistä kuormitusta: urakoinnissa työtaakka siirtyy työhön palkatun harteille, mutta tästä joudutaan maksamaan.

Taulukko 4. Miten merkittäviä seuraavat seikat ovat töidenne ulkoistamisessa?* Kolmen merkittävimmäksi koetun väittämän järjestysnumero on korostettu.

\begin{tabular}{|c|c|c|}
\hline & $\begin{array}{c}\text { Perustuotantotilat }(\mathrm{n}=230) \\
\text { merkittävyys, } \\
1=\text { eniten...9=vähiten }\end{array}$ & $\begin{array}{c}\text { Monialaiset tilat }(\mathrm{n}=433) \\
\text { merkittävyys, } \\
1=\text { eniten...9=vähiten }\end{array}$ \\
\hline $\begin{array}{l}\text { Tiettyjen töiden ulkoistaminen vähentää työperäistä } \\
\text { kuormitusta }\end{array}$ & 1. & 1. \\
\hline $\begin{array}{l}\text { Ulkoistaminen on lisääntymässä, mikä lisää sen } \\
\text { yleistä hyväksyttävyyttä }\end{array}$ & 3. & 4. \\
\hline $\begin{array}{l}\text { Joidenkin töiden ulkoistaminen on taloudellisem- } \\
\text { paa kuin oma työ }\end{array}$ & 5. & 5. \\
\hline $\begin{array}{l}\text { Erikoistuneen urakoitsijan työjälki on ammattimai- } \\
\text { sempaa kuin itse tehdyssä työssä }\end{array}$ & 4. & 2. \\
\hline $\begin{array}{l}\text { Ulkoistaminen oman työn sijaan edistää yrittäjä- } \\
\text { perheen työturvallisuutta }\end{array}$ & 2. & 3. \\
\hline $\begin{array}{l}\text { Yritykseni tuotantoympäristössä on urakoinnin } \\
\text { tehoa heikentäviä tekijöitä }\end{array}$ & 7. & 7. \\
\hline $\begin{array}{l}\text { Tuotantoketjuissa olevat pullonkaulat heikentävät } \\
\text { urakoinnin tehoa }\end{array}$ & 6. & 6. \\
\hline
\end{tabular}

*Järjestysnumeroitu sen mukaan, kuinka monta pistettä väittämä sai vastaajaryhmältä yhteensä skaalalla: erittäin merkittävä (5 p), melko merkittävä (4 p), .., ei lainkaan merkittävä (1 p).

Monialaisilla tiloilla koettiin, että urakoitsija tuo ammattilaatua tuotantoon. Sen sijaan urakointipalveluita käyttävät perustuotantotilat ajattelivat näin vain jossain määrin. Monialaisten tilojen näkemystä voitaneen perustella mm. sillä, että työhön erikoistuneella urakoitsijalla on todennäköisesti nykyaikaisemmat ja tehokkaammat koneet kuin heidän asiakkaillaan keskimäärin sekä runsaasti kokemusta erilaista työtilanteista useilta tiloilta. Erityisesti perustuotantotiloilla mutta myös monialaisilla tiloilla koettiin, että töiden ulkoistaminen edistää yrittäjäperheen työturvallisuutta. 


\section{Tulosten yleistettävyys}

Tässä artikkelissa alustavasti analysoidut kyselyaineistot kuuluvat määrällisesti suurimpiin tätä aihealuetta koskeviin selvityksiin maassamme. Tulosten päälinjat kuvannevat hyvin maatilatalouden keskeisten töiden organisointia sekä yrittäjien asenteita tilayhteistyötä ja töiden ulkoistamista kohtaan keskikokoisilla ja niitä jossain määrin suuremmilla tiloilla. Niiden sekä maamme suurimpien tilojen joukosta löytyvät todennäköisimmin tuotantoaan edelleen kehittävät ja pitkään jatkavat tilat, mikä parantaa tulosten pysyvyyttä.

\section{Johtopäätökset}

Maatalousyrityksen tuotantokapasiteetti on yhdistelmä yrityksen työvoiman määrästä ja osaamisesta, tuotantorakennuksista, karjasta, pelloista ja metsästä sekä tuotantotekniikasta (koneet ja laitteet). Toimintaansa kehittävillä maatalousyrityksillä on kannattavuuden parantamisessa käytännössä kaksi päävaihtoehtoa: tilan nykyisen tuotantokapasiteetin käyttöasteen nostaminen joko alkutuotantoa tehostamalla tai hajauttamalla tuotantokapasiteettia myös alkutuotannon ulkopuolelle eli monialaistamalla. Tuotannon tehostaminen - yleensä yksikkökustannusten pienentäminen - on tilakohtainen yhdistelmä töiden organisoinnista, uuden tuotantotekniikan tai tuotantorakennusten hankinnasta, tai olemassa olevan rakennuskannan peruskorjauksesta ja laajentamisesta, sekä karjamäärän tai peltopinta-alan kasvattamisesta.

Alkutuotannon tehostaminen ja monialaistaminen eivät ole toisiaan poissulkevia kehitystapoja. Moni kotieläintuotannosta luopunut yrittäjä jatkaa ja laajentaa tilallaan esimerkiksi viljanviljelyä ja samalla laajentaa myös yritystoimintaansa esimerkiksi koneurakoinnilla. Urakoinnille on puolestaan kasvavaa kysyntää erityisesti laajentavilla perustuotantotiloilla. Voidaan siis väittää, että tuotantoaan uudelleen suuntaavat tai asteittain alas ajavat maatalousyritykset mahdollistavat yritystoiminnan kehittämisen tai ainakin edistävät sen kehittämistä sekä perustuotanto- että monialaisilla tiloilla ja hyötyvät tästä samalla itse.

Tämän tutkimuksen ehkä yllättävin löydös on, että kaikista kp-tiloista vain noin kymmenesosa ja lypsykarjatiloista vain viisi prosenttia tekee kaikki tilan keskeiset maatilatalouden työt omin voimin. Lopuilla kp-tiloista - näin ollen mitä ilmeisimmin valtaosalla maamme keskikokoisista ja sitä suuremmista maatalousyrityksistä - vähintään muutamia maatilatalouden töistä on joko ulkoistettu tai tehdään tilayhteistyössä. Maatalousyrittäjät kokevat selvästi hyötyvänsä tilayhteistyöstä ja töiden ulkoistamisesta.

Maatalousyrityksen töiden huolellinen suunnittelu ja järkevä organisointi ulkoistamalla, tilayhteistyöllä tai niiden ja oman työn yhdistelmillä ovat keinoja parantaa yrityksen tuotantokapasiteetin käyttöastetta. Töiden organisointikeinot eivät ole toisiaan poissulkevia. Tämän tutkimuksen mukaan kuvaavaa maamme keskikokoisille ja sitä suuremmille maatalousyrityksille on monimuotoisuus töiden organisoinnissa.

\section{Kiitokset}

Kirjoittajat haluavat kiittää hankkeen rahoittajaa, erittäin aktiivisen ja rakentavan ohjausryhmän jäseniä sekä kaikkia kyselyihin vastanneita maaseutuyrittäjiä.

\section{Kirjallisuus}

Karttunen, J. 2004. Maidontuottajien teknologiavalinnat suurissa tuotantoyksiköissä. Työtehoseuran julkaisuja 394. $73 \mathrm{~s}+25$ liites.

Karttunen, J., Suutarinen, J., Leppälä, J., Louhelainen, K. \& Tuure, V-M. 2006. Suhteellisesti vaarallisimmat maataloustyöt. Työtehoseuran julkaisuja 397. $75 \mathrm{~s}+17$ liites.

Kirkkari, A-M., Kallioniemi, M. \& Martikainen, J. 1998. Maatilojen välisen tuotannollisen yhteistoiminnan kehittäminen ja analyysi. Työtehoseuran monisteita 2/1998 (62). 92 s.

Lätti, M., Koikkalainen, K., Kuisma, M. \& Lötjönen, T. 2006. Luomutilojen yhteistyö. Työtehoseuran julkaisuja 396. Helsinki. 89 s.

Niemelä, T., Heikkilä, E. \& Meriläinen, T. 2005. Monialainen yritystoiminta Keski-Suomen maatiloilla. Jyväskylän yliopisto. Taloustieteiden tiedekunta. N:o $148.58 \mathrm{~s}$.

Peltola, A. 2000. Viljelijäperheiden monitoimisuus suomalaisilla maatiloilla. Väitöskirja. Maatalouden taloudellinen tutkimuslaitos. Julkaisuja 96. $280 \mathrm{~s}$.

Rantamäki-Lahtinen, L. 2004. Maatilojen monialaistaminen - Empiirinen analyysi monialaisuuteen vaikuttavista tekijöistä. Maa- ja elintarviketalous 50. Maa- ja elintarviketalouden tutkimuskeskus. $131 \mathrm{~s}$.

Suomen Gallup Elintarviketieto Oy. 2005. Maatalouden kehitysnäkymät -viljelijäkysely (n=4 100). Yhteistyökäytännöt maatiloilla.

Tike. 2007. Maa- ja metsätalousministeriön tietopalvelukeskuksen tilasto maatalouden muusta yritystoiminnasta. Saatavana internetistä: http://www.mmmtike.fi/fi/index/tiedotteet/2006/060510_monialaiset_maatilat.html 